\title{
THE PRICING OF AUDIT SERVICES: EVIDENCE FROM ROMANIA
}

\author{
Professor PhD Atanasiu Pop, „Babeş-Bolyai” University of Cluj-Napoca, \\ e-mail:apop@econ.ubbcluj.ro \\ PhDOana - Raluca Iosivan, e-mail: ralucaiosivan@yahoo.com
}

\begin{abstract}
The main objective of this study is to investigate factors influencing the amount of external audit fees in Romania. Of particular interest is the examination of the potential effect of the client size, client complexity, and the size of the audit firm on external audit fees. An audit fee model is used to examine the effect of audit client size, client complexity, and the size of the audit firm on the amount of audit fees for a sample of audit engagements performed in the tow of Romanian major counties. The study's results indicate that the amount of external audit fees is significantly influenced by the audit client size, by the amount of turnover, by the number of employees. This study is original since it is the first to empirically investigate factors influencing the pricing of audit services in on Romanian audit fee market.
\end{abstract}

Keywords: Romania, Auditor's fees, External auditing, Auditors, Modelling

JEL Codes: M42, L84

\section{Introduction}

The utility of a scientific research resides in the necessity of giving answers to some current, very concrete, questions that may contribute to a better understanding of the phenomenon. The present paper, The Pricing Of Audit Services: Evidence From Romania proposes itself to demarcate the most important concepts in the field of financial audit, contributing to the organic and functional analysis of the auditing process with its most significant elements, techniques and work tools.

This paper represents a research upon the social impact of the financial auditing phenomenon, which is performed by abiding by two essential main demarcation principles: space and time. Therefore we have in mind both the evolution in time of the phenomenon and its determinant factors, and also the extent of the development of the financial auditing phenomenon.

Inside the financial auditing phenomenon, at the interface phenomenon - society, we can speak of only one monetary quantified parameter: the auditor's fee. The analysis of the three components of the Romanian financial audit service market: demand, offer and price (i.e. the quantum of the fee) as well as of the two directly involved parts (i.e. the auditor and the audited), is mainly oriented towards the third element, price, meaning fee. This element is the hardest both to be determined and to be correlated with the factors influencing its quantum.

The interest for studying the announced field is extremely high. In present (M.L.DeFond, J.R. Francis, 2005, 5-30), the main directions of research in the field of auditing underline five chief aspects: identifying the methods of study that would certify and discipline the audit in a rigorous scientific fashion; investigating the problems arising in the context of the fundamental changes undergone in the institutional arrangements; improving the auditor's autonomy; establishing the theoretical basis of the existence of the Audit Committees and underlining their advantages and disadvantages; emphasizing the quality of the financial auditor.

In what concerns the improvement of the auditor's autonomy, the above cited reference study mentions that one of the most important trends of research is the attempt in establishing the theoretical basis and scientific (statistical and mathematical) methods of quantifying the fees 
proposed by the auditor; independently of their nature, fees for financial audit services or other non audit services. Our analysis, in its attempt to find the factors influencing the quantum of the fees on the Romanian audit services market, subscribes to the third path of research.

The present study is an attempt to analyse the social impact that the phenomenon has upon the Romanian economy in the perspective of a dimension with quantifiable effects of great importance for the main two parties involved in the auditing process: the auditor and the audited.

The quasi-exhaustive analysis of the Romanian specialized literature in the domain, up to the date of completion of the present study, gives us reason to state that: if the conceptual delineation component of the audit and its methods, techniques and operational instruments is extensively taken into discussion in many academic sources, there is no published work dealing with the problem of price quantification of the audit services on the Romanian market. No geographical or any other kind of interpretation of the focused problem has been researched on any segment of the economic market, nor at the level of any segment of the services market in Romania. The classical ideological trends in the evolution of the Romanian accounting system, and the powerful influences that for several, well defined, segments of time marked its economic history, and we refer here to the Russian, French and Anglo-Saxon influences, we can undoubtedly draw the conclusion that the Romanian audit services market is not a homogenous one at all.

As far as the Romanian audit services market is concerned we can affirm that: the market is not characterized by a natural birth of the audit services, nor by a large scale internal audit; the demand and offer did not have a normal birth, and the exponential evolution of the financial auditing phenomenon was imposed by law in Romania, it did not appear out of a fundamental wish of the market entities.

For the practical part we have chosen an explicative type of research, having as a purpose the putting to value of the relationships between the phenomena: the way certain parameters (e.g. turnover, total assets, the number of employees), influence the quantum fee of the auditor. In the explicative part we notice the appearance of the possibility of making predictions.

Over the last two decades, the Anglo-Saxons entail a type of research in the field of accounting holding a similar validation process, and which claims knowledge based on empirical validation. The research process we refer to is known under the name of accounting positivism, endorsing the elaboration of empirically tested hypothesis. On basis of the observation data the positivists attempt the identification and explanation of a certain predictable human behaviour.

Our thorough research represents an attempt of a contribution to the alignment, under qualitative and quantitative aspects, to the positivist trend in audit, where observations can be formulated only if they are sustained by a well shaped theory.

Milton Friedman, the 1976 winner of the Nobel Prize for economics affirmed that: theory must be evaluated based on its forecasting power over the class of phenomena it is meant to explain. Only the material fact can prove if it is right or wrong, or better said if it should be temporarily accepted as valid or rejected ${ }^{1}$.

Through the analysis of the evolution of the quantum fee/fee quantum according to some parameters that can or can not be determined, our investigation pursues the behavioural aspect of the phenomenon, respectively the psychology of audit.

\section{Literature review}

Since, Simunic (1980) innovative article, several audit studies were carried out to examine factors expected to influence the pricing of external audit services. The main objective of these

\footnotetext{
${ }^{1}$ n.t. (translation of the quote from the romanian version) F. Milton - Metodologia ştiinței economice pozitive, Editura Humanitas, București, 2004; (teoria trebuie judecată în funcție de puterea ei predicativă pentru clasa de fenomenele pe care este menită să le explice. Numai materialul faptic poate să atare dacă ea este corectă sau greşită, mai bine zis dacă trebuie provizoriu acceptată ca valabilă sau trebuie respinsă)
} 
studies has been to identify those factors that have an effect on the amount of external audit fees. These studies have included studies conducted in the USA (Simunic, 1984; Francis and Simon, 1987; Palmrose, 1996; Gist, 1992), in the UK (Taylor and Baker, 1981; Taffler and Ramalinggam, 1982; Chan et al., 1993; Pong and Whittington, 1994; Che Ahmad and Houghton, 1996), in Australia (Francis, 1984; Francis and Stokes, 1986; Jubb et al., 1996; Craswell and Francis, 1999), in New Zealand (Firth, 1985; Johnston et al., 1995), in Canada (Chung and Lindsay, 1988; Anderson and Zeghal, 1994); in Japan (Taylor, 1997), in Singapore (Low et al., 1990), in Hong Kong (DeFond et al., 2000), in India (Simon et al., 1986), in Pakistan (Simon and Taylor, 1997), and in Bangladesh (Waresul Karim and Moizer, 1996). These studies have typically used audit fees models similar to that initiated by Simunic (1980), with the generic variables proxying for the audit client's size, complexity, and riskiness consistently retained in these models.

Another variable that has been typically examined by much of the audit fees research is the size of the audit firm. Studies examining the potential effect of such a variable were interested in answering the question of whether fees paid to "Big" audit firms are higher than fees paid to "nonBig" audit firms. Findings about the effect of this variable on external audit fees are mixed however, with some studies reporting an evidence of a fee premium paid to "Big" firms (Palmrose, 1996; Francis and Stokes, 1986; Chan et al., 1993), and other studies failing to find an evidence of such a fee premium (Firth, 1985; Chung and Lindsay, 1988; Brinn et al., 1994).

In what the audit fees model is concerned to develop an explanatory model of external audit fees, it is important to identify those factors expected to cause variability in the amount of audit fees. Studies investigating the pricing of audit services have examined the effect of a large number of variables on external audit fees. However, client size, client complexity, and client riskiness have been typically identified as the key explanatory variables in these pricing models. Audit fee models including these three variables have demonstrated high-explanatory power, and have showed robustness across different samples (DeFond et al., 2000).

One parameter considered in most of this studies is audit client size thus previous audit fees studies (Simunic, 1980, 1984; Maher et al., 1992; Francis, 1984; Firth, 1985; Francis and Stokes, 1986; Palmrose, 1996; Simon and Francis, 1988; Taylor and Baker, 1981; Chung and Lindsay, 1988; Chan et al., 1993; Craswell and Francis, 1999; DeFond et al., 2000) have consistently reported evidence revealing the existence of a direct relationship between the amount of audit fees and the audit client size. Naturally, we would expect such a positive relationship between audit fees and client size to exists, since the external audit firm is expected to perform more audit work as the client size increases to ensure the performance of an adequate amount of compliance and substantive testing. This increase in audit effort is naturally expected to be associated with an increase in the amount of audit fees.

The relationship between audit fees and client size is unlikely to be linear nonetheless. This conjecture is based on the notion that while the amount of audit work is expected to increase as the client size increases, very large audit clients represent an opportunity for the audit firm to benefit from certain economies of scale in reducing the amount of audit work performed, and consequently being able to charge lower audit fees (Gerrard et al., 1994). Moreover, The audit fees literature is replete with evidence suggesting that external audit fees increase at a decreasing rate with the audit client size (Simunic, 1980, 1984; Maher et al., 1992; Francis, 1984; Francis and Stokes, 1986;

Palmrose, 1996; Simon and Francis, 1988). Such research maintains that the relationship between audit fees and client size is unlikely to be linear. Thus, the natural log of the client's total assets has been typically used in most previous research as a measure of the audit client size.

Audit client complexity - one other important factor to be considered so, prior research (Simunic, 1980; Francis, 1984; Francis and Stokes, 1986; Maher et al.,1992; Chan et al., 1993; Che Ahmad and Houghton, 1996; Carcello et al., 2002) documented empirical results indicating that audit fees are significantly influenced by the level of the audit client complexity. Hypothetically, we would expect that as the audit client becomes more complex, more time and effort is needed to 
perform the external audit work. This is true because a more complex audit client means a more diverse organizational structure, and harder to review transactions. This increased audit effort is expected to lead to an increase in the level of audit fees.

About the audit client risk existing research Simunic (1980) indicates that audit fees is a function of both the cost of performing the audit (including a normal profit) and the expected cost of the audit risk. Audit risk is the risk that the external audit firm will be held liable to third parties for damages related to misstatements in the audited financial statements. Audit firms adjust for an increase in the audit risk level by either increasing their audit effort (to reduce the chance of undetected misstatements), or charging a premium to compensate themselves for the increase in audit risk (Simunic, 1980; Pratt and Stice, 1994; Seetharaman et al., 2002). Thus, we would expect the external audit firm to charge higher audit fees when the audit risk increases. Previous audit fees literature provides evidence consistent with this argument. In particular, audit firms were found to charge higher external audit fees when the audit engagement risk increases (Simunic, 1980; Simon and Francis, 1988; Palmrose, 1996). As indicated by prior research (Chan et al., 1993), audit risk, which indicates the risk associated with performing the audit engagement, is hard to measure. While the author is aware of this fact, this study is no exception to the general approach followed by previous audit fee literature, which have commonly used balance sheet measures to proxy for this risk.

Audit firm size, as indicated, several audit fee studies were interested in examining whether audit fees paid to "Big" audit firms are significantly higher than fees paid to "non-Big" firms. There are three main grounds for such an inquiry. First, Big audit firms are said to provide a higher level of audit quality than "non-Big" audit firms (DeAngelo, 1981). Second, the "deep pocket" hypothesis suggests that, since "Big" audit firms are "wealthier" than "non-Big" audit firms, in the case an audit client company went bankrupt, audit report users (e.g. creditors, and shareholders) would be more allured to file lawsuits against "Big" audit firms. This higher level of litigation risk exposure is expected to be associated with higher levels of external audit fees charged to compensate for such exposure risk. Third, the non-competitive pricing hypothesis suggests that, especially in the large clients segment of the audit market, "Big" audit firms face less competition than "non-Big" firms and therefore are able to charge higher audit fees.

The effect of the audit firm size on audit fees was examined by several audit studies. However, empirical examination of this issue has often yielded mixed results. In the USA, Simunic (1980) found no significant differences in audit fees between "Big" audit firms and "non-Big" audit firms for both large and small audit clients. On the other hand, both Palmrose (1996) and Gist (1992), among others, found that audit fees of "Big" audit firms were higher than that of "non-Big" audit firms for small audit clients. In Australia, Francis (1984) and Francis and Stokes (1986) found audit fees of "Big" audit firms to be significantly higher than that of "non-Big" audit firms. In the UK, several studies (Taffler and Ramalinggam, 1982; Chan et al., 1993) found audit fees charged by "Big" audit firms to be higher than fees charged by "non-Big" audit firms, while others (Brinn et al., 1994) did not find evidence of such a premium. In Canada, while Chung and Lindsay (1988) found no significant difference in audit fees between "Big" and "non-Big" audit firms, Anderson and Zeghal (1994) found such a price difference to exist. In Bangladesh, Waresul Karim and Moizer (1996) found that audit fees of "Big" audit firms were statistically higher than that of "nonBig" audit firms. In NewZealand, Firth (1985) found no significant difference in audit fees between "Big" and "non-Big" audit firms.

It appears, therefore, that results obtained from previous research about the potential influence of audit firm size on audit fees are mixed, and that further investigation of this issue is warranted. Thus, the current study does not includes in its examination the potential influence of the audit firm size on the amount of external audit fees, due to the fact that is a geographical typical explanatory study

External audit market, and its audit fee is a topic of study in the economies of both 
developed and emerging economies (Hong Kong, Malaysia, Singapore). However audit services market in emerging economies was given limited attention. Hay and colleagues (2006) conducted a meta-study examining the potential determinants of the amount of audit fees in the past 25 years (1977-2002). Of the 88 works specilitate included in their analysis, only 6 referred to the countries with emerging markets audit, while 45 shall be referred to the United States of America. Hay, believes the study in 2006 that determining factors of audit fees are: the size of the customer, generally risk audit, and the complexity of the customer, customer profitability, company owners, the competitions degree of market share.

As presented we can determine four trends in the international audit fee research, first of all audit fees charged by large companies audit (BIG 4) for services provided to audit financial entities obliged to contract such services. Secondly fees charged by large companies audit (BIG 4) for services provided to audit financial entities obliged to contract such services, depending on the scope of activity of companies audited. One other important trend states that the relationship between the fees charged by large companies audit (BIG 4) on the one hand and other companies audit on the other hand, for services provided to audit financial entities obliged to contract such services and quality of service quality audit. At last the relationship between the fees charged by large companies audit (BIG 4), for services provided to audit financial entities obliged to contract such services acting in different segments of industry are substantially different.

As an intermediate conclusion we wish to emphasize the common elements of these studies: study of discretion in particular activity firms BIG 4; study of contractual/regulatory (statutory) audit; study of audit clients made a significant scale. study of audit conducted customers in a given industry;

\section{Research methodology}

Research methodology applied in this study consisted in taking the following stages: in a first stage, the most important achievements in the field were studied by means of the literature in the special field; in a second stage conceptual elements of the model were determined, namely the parameters to take in consideration for its establishment; in a third stage a statistical program for data processing was used to establish correctly correlations, co-variations of parameters; in the fourth stage, by means of the same statistical programme a linear model of mathematical regression was established to measure the amount of fees according to various parameters; in a last stage it was chosen the model which was the most stable from statistic point of view and more relevant for establishing the amount of fees according to a series of parameters that researcher considers relevant.

The author can afford to state that for this applicative study, the type of research employed is basically the explanatory research with the purpose to turn into good account the relations between phenomena: the influence of some parameters (turnover, total assets, number of employees), the amount of auditor's fees. This explanatory research gives us the opportunity to make some predictions.

In all scientific domains, we can distinguish two types of researches from the point of view of the targeted purpose; respectively fundamental researches and applicative researches. In the filed subject to research, fundamental research analyzes audit as an historical, social and organizational phenomenon, defining the concepts, the methods and the functions of this domain; and the applicative research proposes new methods for the improvement of audit in such a way as to meet the actual needs of the players involved in the process.

The subject chosen to be the subject of research is the audit phenomenon which is examined as it is perceived by the players involved at the level of the Romanian economic company. Concerning the study performed, we intended to analyze and express pertinent opinions concerning: the existing correlation between the size of the entity and the voluntary request for 
financial audit, its age and the existence of a service of internal control and / or internal audit; the relation between the financial auditor and the accountant of the entity subject to auditing, the correlation between the quality of financial-accounting information supplied to users and the auditing of this information.

This empirical research was carried out on the following segments of interest: the degree to which audit services are regarded as necessary, at the three levels: at the management level, outlined by signing a contract of audit even when not required by law; at the level of the professional accountant employed within entity; at the level of the external information user;

Time fences since financial audit is performed; average amount of fees paid to the auditor; the extent to which the auditor interrelated with the entity; the nature of auditor - accountant relations, the extent to which the financial audit would bring about a better information of users; the extent to which financial audit helps the work of the professional accountant; the development degree of internal audit; the interdependence between the department of internal audit and that of internal control; the need to resort to consultancy services in the field of audit and accounting;

After having chosen the subject of research, the following stage consisted of formulating the hypotheses trying to explain the phenomenon they study by establishing some general principles and an organized concept system.

Therefore, we concluded that the design parameters are: inclusion of audit services only, inclusion of all entities which have their financial statements audited, not only those which are compelled by law; inclusion of entities in this study by geographical demarcation. The final objective was to obtain such a function and to create a basis for the future conceptualization at the level of Romanian market of such a quantification system.

\section{Methodology - Sample}

To estimate the external fees model, data were collected via survey from 401 participants to the CPA exam, in July 2007, and the collected data is for 2004-2006 period. This is only a part of a greater study.

The survey included items designed to collect data required to investigate some audit engagement characteristics hypothesized to be influential in the pricing of audit services. More specifically, the survey included items designed to collect data related to the following variables: the amount of external audit fees, the number of audit locations of the audit client, and some financial statement

variables of the audit client.

In all, 101 surveys were received, of which 2 were excluded because of missing data. Hence, the study's final sample consists of 60 audit engagements with 2004,2005,2006 fiscal-year ends that were performed by both "Big" and "non-Big" audit firms.

\section{Model specification}

This study uses a parsimonious audit fee model consisting of explanatory variables commonly Believed to be key determinants of external audit fees. Since the primary focus of this study is to test the usefulness of the key fee determinants in explaining variability in the amount of external audit fees in a geographicly demarcative zone in Romania, the selection of variables to be included in the fee model was limited to variables measuring client size, client complexity, audit risk, and the size of the audit firm. These explanatory variables are included in a cross-sectional audit fee regression model analogous to fee models employed by prior research to test for their potential influence on external audit fees. 
Following the research, the author found a certain number of valid ceteris paribus functions that states direct links between the audit fee, and four of the parameters in study.

\begin{tabular}{|cc|}
\hline 1. Audit fee (Shareholder's equity) $=\mathrm{e}^{-2} * 4,45376 *($ Shareholder's equity $)+$ & 4252.685 \\
$(0 \%)$ & $(0 \%)$
\end{tabular}

and

\section{Audit fee ( Turnover) $=\mathrm{e}^{-2 * 3,22023} *$ Turnover $+2359,827$}

$(0 \%)$

$(0 \%)$

and thirdly

\section{Audit fee (Total Assets) $=\mathrm{e}^{-2 * 1,76025} *$ Total Assets $+2650,971$}

(0\%)

$(\mathbf{0 \%})$

at last

4. Audit fee (Number of employees) $=14,66388 *$ No Employees+ 891.0366

$(0 \%)$

$(12,1 \%)$

the stable statistical and mathematical model for our function:

Amount (T.A., TO, Emp, $)=\mathrm{e}^{-3 * 4,7942 X 1+\mathrm{e}^{-3} * 11,4516 X 2+6.607156 * X 3+1766.82}$
$(10,2 \%)$
$(0 \%) \quad(0,1 \%)$

Where : X1 - Total assets; X2 - Turnover ;

X3 - Average number of employees;

For conceptualization, we can say that existing function is:

Amount $=\alpha_{0}+\alpha_{1}$ Total Assets $+\alpha_{2}$ Turnover $+\alpha_{3}$ Number of employees;

\section{Econometric approach}

\section{1) Model}

We estimate the econometric model in cross section (without time dimension or with a time dimension very low, 5 years for instance):

quantum $_{i}=\alpha_{0}+\alpha_{1}$ assets $_{i}+\alpha_{2}$ TO $_{i}+\alpha_{3}$ emp $_{i}+u_{i}$

$\alpha_{0}$ is a constant and $u_{i}$ represents model remainders.

Short duration (4 years) reduces risks of correlations between shocks, as well as nonstationarity problems (although potential variables such as TO or ASSETS and EMP may be nonstationary, namely the increase continuously in time). This involves the fact that the model can be estimated according to least squares method (LSM)

Commands from STATA $=$ first line of the table

Number of obs $=33$ observations

\section{2) Tests-}

Ordinary test $\alpha_{1}=\alpha_{2}=\alpha_{3}=0$ may be carried out by means of a Fisher test, with 3.29 degreees of freedom. High value of test is confirmed by a very low significance level Prob $>F$; this means that null hypothesis is rejected in the case of each of the three traditional significance thresholds, namely at least one of the coefficients $\alpha_{1}, \alpha_{2}$ and $\alpha_{3}$ is significantly different from 0 .

Individual tests: for each coefficient, it is calculated the average deviation (std error) as radical of 2 order from the variant, defined as the product of the squares of differences between each value and average value divided by the number of observations. Individual significance of 
each coefficient may be testes by a simple student test (t-stat), which is calculated as a ratio between the estimated coefficient, test value and average deviation. For instance, to test significance (importance) of coefficient assets (if different from 0), it is calculated : $t-$ stat $=\frac{\alpha_{1}-0}{\sigma_{\alpha_{1}}}$. Thus t-stat can be calculated very easily from table.

This value is compared to the value in the student distribution table, which is to be read for a certain number of degrees of freedom (29 in this case), a certain significance threshold (1;5 or 10\%) respectively; moreover we should also keep in mind that the test in relation to 0 has to be built, by definition, as bilater. In order to simplify everything, there is a simpler method: the computer calculates the significance level $\mathrm{p}>\mathrm{t}$ (the fact that $\mathrm{t}$ is in modulus shows that it is a bilater test). The interpretation of this level is the following: the coefficient is significantly different from zero in the event that $\mathrm{P}>\mathrm{t}$ is SMALLER than the significance threshold we set. For instance the coefficient of TO is different from 0 at the threshold of $10 \%$, but it is not significant at the thresholds 5 or $1 \%$, and the constant and the coefficient emp are both significant for the three thresholds. As far as interpretation is concerned, a more flexible mode is accepted, in the sense that in our regression all coefficients are considered as significant. For this reason, the global test $\mathrm{F}$ is of a great significance.

The confidence interval 95\% Conf Interval has the same significance as for $\mathrm{p}>\mathrm{t}$. for instance, with a confidence of $95 \%$ (or a threshold of 5\%), the coefficient assets ranges within that respective interval. We should keep in mind that at 5\% this coefficient is not significant, namely it may be equal to 0 . As it can be seen, the figure 0 can be found within the confidence interval at $95 \%$, which confirms our previous interpretation.

\section{3) Interpretations}

R2 factor is very high, which involves the fact that our model succeeds in explaining the variation of amount variable in a percentage of $94 \%$. Usually, it is preferred a R2 adjusted according to number of $\mathrm{DF}=$ degrees of freedom, but it is also very high. There is a close relation between significance of $F$ test and value of $R 2$, in the sense that $F$ test may be entirely built based on R2 ( and on the number of degrees of freedom).

As coefficient are positive, it means that there is a favourable effect of active variables TO [turnover] and EMP [employees], on the explained amount variable. It is interesting the emergence of a scale effect, between the second and the third variable due to the fact that probably, the variable of the number of employees (emp) has smaller values, while the first two variables have very high values

\section{Model Testing}

Any statistical model has to be tested to see whether it is valid. Therefore I have tested this statistical model for the data gathered to see results. I reached the following conclusions: model was confirmed with deviations of up to $2 \%$ for all entities subject to testing and which are compelled by law to audit their financial statements ; model was confirmed with deviations of up to $10 \%$ for $37 \%$ of entities which are not compelled by law to audit their financial statements;

I consider that this survey cannot be conceptualized and applied on a large scale for all types of audit services and for all types of entities as it was confirmed for the market segment of voluntary audit services but in a percentage of $37 \%$; neither can it be used for conceptualization for market segment of legal audit services as statistical population comprised also entities which audited their financial statements although they were not compelled by law to do so, but it can be conceptualized if we have in mind a segmental approach of audit services market as a first step was already made by the survey carried out which proved the possibility of mathematical modelling and of obtaining a linear regression function, even for a statistical population which was chosen based on demarcation criteria. 


\section{Summary and conclusions}

The main objective of this study has been to see whether the key audit fee determinants identified by prior audit research (namely client size, complexity, and audit firm size) prove to be relevant in determining the amount of audit fees in the sample studied. Consistent with expectations, the study's results showed that the amount of audit fees in the two counties of Romania is positively related to the audit client size measured by total assets. This finding is similar to that obtained by numerous audit fee studies performed in several countries.

I therefore conclude that for future researches it is necessary a segmental approach of the market. According to literature studied approach of audit fees in the literature in the special field and international practice, the common rule is a segmental approach of audit services according to the following criteria: both their legal and statutory obligation, and denomination as business segment, size of audited entity, and the criterion of geographical delimitation of entity location can also be found.

I consider that main criteria to be taken into consideration for the audit services market in Romania shall be the following: legal obligation to carry out the audit and entity size, membership of a certain business segment, property type (mainly state-owned, mainly private).

Qualitative parameters quantifiable by means of dummy variables to be taken into consideration for the future quantification models are as follows: auditor's membership or nonmembership of BIG4, subsidiarily auditor's functioning as body corporate or self-employed person, existence of foreign subsidiaries of audited entity, auditor's opinion, whether pertinent or not, existence of a clash of interests at the level of top management (it is possible to have the general manager involved by holding or not holding shares), existence or inexistence of controls to operate significant corrections performed by Inland Revenue Service.

I also consider that this survey should have benefited from a longer time exposure of statistical data; existence of an audit services market in Romania, with time fences of not much more than six years ${ }^{2}$, makes impossible the application of statistical rules concerning data series for a time fences of ten temporal units.

This survey is significant both at national and international level due to its final result: elaboration of a mathematical model for the quantification of audit service fees. It also identifies the possibilities to improve the model, identifies the degree of non-concordance between the elements of statistical population to outline correctly the most important research directions within this research field at the level of Romania.

First of all, lack of such a survey at the level of Romania places importance on our research. Importance of this survey at international level is outlined through the prism of generic conclusions with respect to audit services market - its existence and functionality degree respectively, but also by proposing a negotiation instrument - the model to quantify the fees related to commercial transaction. Other researchers of international scientific / academic community with similar preoccupations may also show interest in our research and they may record the possibility to extend such a survey and address other possible dimensions which may be based, for instance, on geographical grounds.

\section{References}

1. Anderson, T. and Zeghal, D.

2. Anderson, U., Kadous, K. , and Koonce, L.,
The pricing of audit services: further evidence from the Canadian market", Accounting \& Business Research, Vol. 24 No. 95, pp. 195-207, 1994.

The role of incentives to manage earnings and quantification in auditors' evaluations of management-

\footnotetext{
${ }^{2}$ n.a. survey is carried out in 2007;
} 
3. Brandon, D., Crabtree, A. , and Maher, J.,

4. Brickey, K. F.,

5. Brinn, T., Peel, M.J. and Roberts, R.

6. Butler, M., Leone, A. J., and Willenborg, M.,

7. Carcello, J. V., Hermanson, D. R., Neal, T. L., and Riley, R. A.,

8. Chan, D.,

9. Chan, P., Ezzamel, M. and Gwilliam, D.

10. Chung, H., and Kallapur, S.,

11. Chung, D. and Lindsay, W.

12. Craswell, A., and Francis, J.,

13. Craswell, A., Francis, J., and Taylor, S.,

14. DeAngelo, L. ,

15. DeFond, M. L., and Jiambalvo, J.,

16. DeFond, M. L., Jiambalvo, J., and K. R. Subramanyam,

17. DeFond, M., Francis, J. and Wong, $\mathrm{T}$.

18. Ferguson, A., Francis, J. and Stokes, D.

19. Francis, J. R., and Krishnan, J., provided information, Auditing: A Journal of Practice \& Theory 23 (Spring): 11-27, 2004.

Nonaudit fees, auditor independence, and bond ratings. Auditing: A Journal of Practice \& Theory 23 (September): 89-103, 2004.

Andersen's fall from grace, Working paper, Washington University, St. Louis, MO, 2004.

Audit fee determinants of independent subsidiary unquoted companies in the UK - an exploratory study", British Accounting Review, Vol. 26 No. 2, pp. 101-21, 1994.

An empirical analysis of auditor reporting and its association with abnormal accruals, Journal of Accounting and Economics 37 (June): 139-165, 2004.

Board characteristics and audit fees. Contemporary Accounting Research (Fall): 365-384, 2002.

Low-balling and efficiency in a two-period specialization model of auditing competition. Contemporary Accounting Research 16 (4): 609-42, 1999.

Determinants of audit fees for quoted UK companies, Journal of Business Finance \& Accounting, Vol. 20 No. 6, pp. 765-86, 1993.

Client importance, nonaudit services, and abnormal accruals. The Accounting Review 78 (October): 931-955, 2003.

The pricing of audit services: the Canadian perspective, Cotemporary Accounting Research, Vol. 5 No. 3, pp. 1946., 1998.

Pricing initial audit engagements: A test of competing theories. The Accounting Review 74 (2): 201-15, 1999

Auditor brand name reputations and industry

specialization. Journal of Accounting and Economics 20 (3): 297-322, 1995.

Auditor independence, "lowballing" and disclosure regulation. Journal of Accounting and Economics 3 (2): 113-27, 1981.

Debt covenant violation and manipulation of accruals, Journal of Accounting and Economics 17 (January): 145176, 1994.

Auditor changes and discretionary accruals. Journal of Accounting and Economics 25 (February): 35-67, 1998.

Audit industry specialization and market segmentation by big 6 and non-big 6 accounting firms", Auditing, A Journal of Practice and Theory, Vol. 19 No. 1, pp. 49-66, 2000.

The effects of firm-wide and office-level industry expertise on audit pricing, The Accounting Review, Vol. 78 No. 2, pp. 429-48., 2003.

Accounting accruals and auditor reporting conservatism. Contemporary Accounting Research 16 (Spring): 135-165, 1999. 
20. Francis, J. R., and Krishnan, J., Maydew, E. L., and Sparks, H. C.,

21. Francis, J., and Wilson, E.,

22. Francis, J., Philbrick, D. , and Schipper, K.,

23. Francis, J., Philbrick, D. , and Schipper, K.,

24. Johnson, B. W., and Lys, T.,

25. Johnson, E. N., Walker, K. B., and Westergaard, E.,

26. Jubb, C., Houghton, K. and Butterworth, S.

27. Kinney, W. R., Palmrose, ZV., and Scholz, S.,

28. Lee, D. S.,

29. Lee, H. Y., and Mande, V.,

30. Low, L., Tan, P. and Koh, H.

31. Morgan, J., and Stocken, P.,

32. Palmrose, Z.V.,

33. Parker, A.,

34. Pong, C. and Whittington, G.

35. Simon D., Taylor, M. H.,

36. Simon, D., Ramanan, R., and Dugar, A.,

37. Simon, T., and Trompeter,S.,

38. Simunic. D.,
The role of Big 6 auditors in the credible reporting of accruals. Auditing: A Journal of Practice \& Theory 18 (Fall): 17-34, 1999.

Auditor changes: A joint test of theories relating to agency costs and auditor differentiation. The Accounting Review 63 (4): 663-82, 1988.

Shareholder litigation and corporate disclosures. Journal of Accounting Research 32 (Autumn): 137-164, 1994.

The market pricing of earnings quality. Journal of Accounting and Economics 39 (June): 295-327, 2005.

The market for audit services: Evidence from voluntary auditor changes. Journal of Accounting and Economics 12 (1 -3): 281 -309, 1990.

Supplier concentration and pricing of audit services in New Zealand, Auditing: a Journal of Practice \& Theory, Vol. 14, Fall, pp. 74-84.

Audit fees: the plural nature of risk, Managerial Auditing Journal, Vol. 11 No. 3, pp. 25-40, 1996.

Auditor independence, non-audit services, and restatements: Was the US government right? Journal of Accounting Research 42 (June): 561-588, 2004.

Auditor market share, product differentiation and audit fees, Accounting and Business Research, 1996, Vol. 26, No. 4.

The effect of the Private Securities Litigation Reform Act of 1995 on accounting discretion of client managers of Big 6 and non-Big 6 auditors. Auditing: A Journal of Practice \& Theory 22 (March): 93-108, 2003.

The determination of audit fees: an analysis of the Singapore context", Journal of Business Finance \& Accounting, Vol. 17 No. 2, pp. 285-95, 1990.

The effects of business risk on audit pricing. Review of Accounting Studies 3 (4): 365-85, 1998.

An analysis of auditor litigation and audit service quality. The Accounting Review 63 (January): 55-73, 1988.

Accounting profession clashes with regulator over attack on "lowballing". Financial Times, June 29, 2, 2002.

The determinants of audit fees: some empirical models, Journal of Business Finance \& Accounting, Vol. 21 No. 8, pp. 1071-95, 1994.

The market for audit services in Pakistan, Advances in International Accounting, 1997, Vol. 10.

The market for audit services in India: an empirical examination, International Journal of Accounting, 1986, Education and Research.

A comparative study of the market for audit services in Hong Kong, Malaysia, and Singapore, International Journal of Accounting Education and Research, 1992, Vol. 27.

The pricing of audit services: theory and evidence, Journal of Accounting Research, Vol. 18, 1980. 
39. Simunic, D.

40. Simunic, D. and Stein, M.

41. Taylor, M. H.,

42. Taylor, M. H., Simon, D. T., and Burton, F. G., uditing, consulting, and auditor independence, Journal of Accounting.

Research, Vol. 22 No. 2, pp. 679-702,1984

The impact of litigation risk on audit pricing: a review of the economic and the evidence, Auditing: A Journal of Practice \& Theory, Vol. 15, pp. 119-34, 1996.

The The market for audit services in Japan, Pacific Accounting Review, December 1997.

A survey of audit pricing in South Korea, Research in Accounting Regulation, 1999, Vol. 13. 